\title{
The Effects of Western Culture on the Family System of Khyber Pakhtunkhwa:
}

\author{
An Overview \\ * Rubina Naz \\ ** Dr. Hashmat Begum \\ *** Dr. Sardaraz Khan
}

\begin{abstract}
The present study aims to explore the effects of Western culture on the family system of Khyber Pakhtunkhwa. Every culture in the world is diversified. Culture is an invisible thing, but its effects can be seen and felt. The most significant changes of the society often come through its cultural norms. This paper discourses the influences of Western culture on the Muslim culture of Khyber Pukhtunkhwa. A qualitative descriptive approach was adopted, and data was collected from books, journals, newspapers, and the internet. Results revealed that there were significant effects of Western culture on the family system of Khyber Pakhtunkhwa. The research concluded that the influences of Western culture come through education, media, the internet, and cell phones.
\end{abstract}

Keywords: Culture, Cultural Change, Family System, Western Culture, Pakhtuns

\section{Introduction}

Man needs the support of fellow beings for living a better life, sustenance and nurture, and requires such a place of living where he feels protection, self-identity, and can live a better life with his relatives. Such a place is termed as a family. Different languages use different terms for family, as it is called khandan in Urdu, al- ${ }^{c}$ Usratu in Arabic, and Khanevadeh in Persian. In the common tongue, it is termed as tribe, family, or clan (Manzur 1988). The Arabic word al ${ }^{c}$ Usratu has been used in several meanings such as family, prisoner, concealing something, strength and maturity, and arrangement and organization (Hafeez 1999). The nurture process of human starts with his/her family, as Allah says in (Quran 4:1),

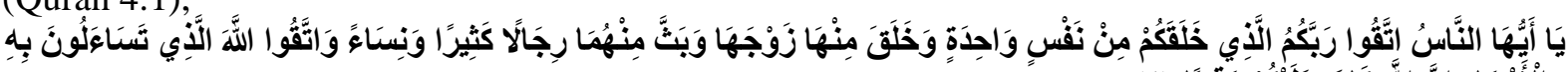

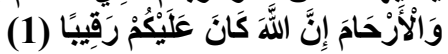

O mankind, fear your Lord, who created you from one soul and created from it its mate and dispersed from both many men and women. And fear Allah, through whom you ask one another, and the wombs. Indeed, Allah is ever, over you, an Observer.

A strong family gives strength to a person and keeps him away from the feeling of weakness or loneliness. Allah says in (Quran 30:21),

And He placed between you affection and mercy.

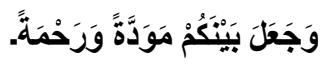

A strong family has a cardinal place in a society. If the family system is based on the right principles and rules, then the society will be stable and strong as well as free from chaos and discord, and its members will cover the path of progress and development easily. In a society, where there are no rules and regulations of the family system, chaos and anarchy prevail. People in a state of restlessness and anxiety will not only harm themselves but may also cause decadence and decline to the society overall. Only a stable family system, based on sound principles, develops a stable and civilized society in which all the members take cognizance of the rights of each other.

Abdullah ibn Umar narrates from the Holy Prophet (Bukhari 1981),

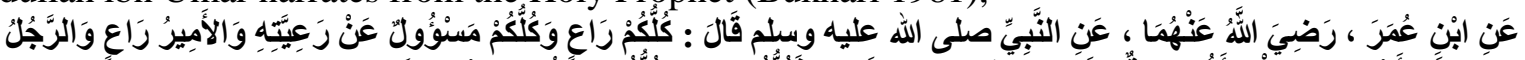

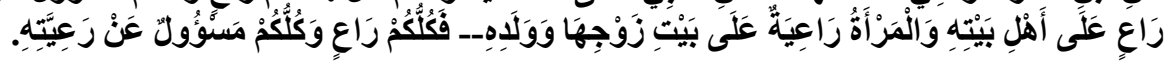

\footnotetext{
* Shaheed Benazir Women University, Peshawar Email: rubisohail@gmail.com

** Shaheed Benazir Women University, Peshawar

*** University of Science \& Technology, Bannu
} 


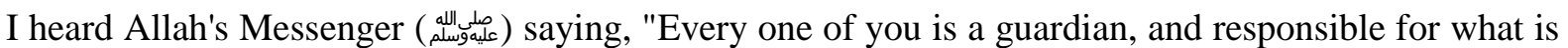
in his custody. The ruler is a guardian of his subjects and responsible for them; a husband is a guardian of his family and is responsible for it; a lady is a guardian of her husband's house and is responsible for it and her children ---- so all of you are guardians and responsible for your wards and things under your care."

\section{Importance of Family System in Islam}

Islam not only gave overall development to the social system, leaving no aspect of it, which does not reflect the well-being of the people, but it also prescribed appropriate laws and principles based on justice for its small and partial divisions and distribution. Islam has ordained for adherence to these rules and regulations to strengthen the social values, because the prosperity or adversity and development and decline of a society rests upon these principles and laws. According to Islam, the dignity of an individual depends on his character and deeds, but as he/she is a member of a family, the basic unit of the social system, therefore, has some obligations towards his family, which he/she has to perform. In Islam, as an individual, male and female, occupies an important position in the family system, therefore, to maintain a legitimate and strong relationship between a man and a woman, Islam has declared marriage necessary. The Prophet said,

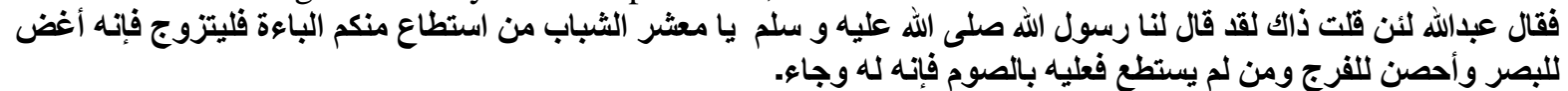

0 young men, those among you who can support a wife should marry, for it restrains eyes (from casting evil glances) and preserves one from immorality; but he who cannot afford It should observe fast for it is a means of controlling the sexual desire (Muslim 2014).

Marriage is the only way to maintain a strong family. Islam neither believes in monasticism nor gives free rein for sexual gratification. In the Islamic moral system, all members of the family have the sense of their respective obligations and duties, and they neither neglect their duties nor the rights of others. Allah says in the (Quran 13:38)

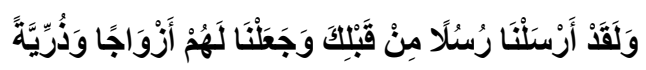

"And we have already sent messengers before you and assigned to them, wives and descendants."

\section{Pre-Islamic Family System}

In pre-Islamic society, besides many other evils in the family system, amour and love was regarded as a yardstick for the status of the family. Moreover, women had no status in the family system of that time. The Arabs had specific ideas about women, and women were deprived of human and social rights. Woman was stigmatized as a source of humiliation and disgrace for the family, and therefore, the Arabs used to bury alive their daughters. They had no share in the inheritance. Marriage to the father's wife was not prohibited by law on the death of her husband, and after the death of the husband, his eldest son would either marry her himself or would marry her to someone else and took her dowry himself or would refuse her matrimonial rights and took all of her property. Moreover, in pre-Islamic Arabs, the family system was lacking the foundation of principles and code of ethics due to which they were often engaged in internecine conflicts which weakened them and made them degraded in the eyes of other nations.

In the pre-Islamic world, there were no laws, codes, and principles for the family system, and thus, there was no concept of the family system in the societies. Each house, tribe, and family had its own rules. No one had the sense of their duty and care for the rights of others. There was no welldefined system for the rights of parents, husband and wife, and the relatives. Lacking any codified system based on principles of justice, they were often involved in internal fights, which created chaos in the society.

\section{Western Family System}

The West today, despite being advanced in every field, is facing the problem of a chaotic family system. Its family system is on the verge of collapse. The basic reason for this collapse is their attempt to organize their family system on the tenets of their newly constructed theories and philosophies like the Arab tribes before Islam. Homosexuality is legalized in many Western countries. Institutions such as old age homes, baby daycare centers, orphanages, etc. have been established. This means that parents should be referred to an old age home in old age, children should be brought up in daycare centers and young female should be sheltered in Darulaman. In Schools admissions, the name of the mother is recorded with a kid, because of the lack of identity concerning his/her father. The tradition of marriage is going to an end, and there is no law for the gratification of sexual desires. One of the 
most recent trends is the concept of a baby test cube to produce kids in return for money. Moreover, punishment of a kid for inculcating even moral values is a criminal act within the western societies nowadays. Despite free sex, rape is on the rise. Incidents of forced adultery with daughters, sisters, etc. are increasing.

The basic reasons for the deterioration of the Western family system are the ideas and thoughts which flourished in the west. Those principles which they found good and useful for themselves were made the principles of the family. He abolished all kinds of restrictions on individuals and made man free with no obligation to his or her family. They do not have the guiding principles to establish and strengthen the family.

Gorbachev writes in his book Reconstruction of Socialism that they should have tried to implement the principles of the Eastern social system in their social system. He argues that it is because they did not give those rights to the women of their society nor cared about their needs, which should have been given to a woman as a mother and as the sustainer of a family. The main reason for such a situation is that women in western societies are engaged in scientific research and creative works, which cause their distancing from the household affairs and upbringing of children. These factors have led to behavioral problems in their youth and moral and cultural issues in their society. The disruption of the family system is because of entrusting women with the duties and obligations of men in all matters. To restore the situation, debate has started in public organizations, press, and workplaces and at home to suggest recommendations for bringing women to their natural duties and obligations (Toru n.d.).

The reason for the disintegration of the Western family system is that men and women cannot trust each other. They have an environment of uncertainty that has engulfed the whole society. The divorce rate has increased. Life without marriage, an increase in adultery, considering parents a burden, and restless matrimonial life have completely ruined the family system. A family devoid of rules and regulations can never lead to the stability of any society. The roots of such societies are slowly undermined leading to greater destruction.

\section{Culture}

Culture, in simple terms, is a way of life (Williams 2018), and according to Tyler as cited by (Avruch 1998) p.6 "is that complex whole which includes knowledge, belief, art, morals, law, custom, and any other capabilities and habits acquired by man as a member of society." These behavioral patterns, habits, thoughts, actions and customs, and values, which we adopt in our family system, are termed as family culture. Sociologists define culture as "a fuzzy set of basic assumptions and values, orientations to life, beliefs, policies, procedures and behavioral conventions that are shared by a group of people, and that influence (but do not determine) each member's behavior and his/her interpretations of the 'meaning' of other people's behavior." (Spencer-Oatey 2008) p.3. Thus, culture is a legacy of the past as well as an experience for the future. Culture is related to the overall habits and customs of a country and a nation. Human education and training play a major role in the field of culture. Culture is not only customs, habits, and ideas, but it also includes strong and stable customs and traditions which are based on Islamic practices. There are some traits in the habits and customs of some families which cannot be categorized as culture.

\section{Culture of Khyber Pakhtunkhwa \\ Hospitality}

Every region, nation, and country in the world has its unique characteristics, due to which they become popular. Khyber Pakhtunkhwa is known across the world for its hospitality, friendship, bravery, and courage. Hospitality has a special status in the culture of Khyber Pakhtunkhwa. The people here consider hospitality as their glory, honor, and generosity. Guests are welcomed at every moment, and they are regarded as the guests of the whole village (Khattak 2008).

\section{Hujra}

Hujra is a place where everyone in the village is present for hospitality. Hospitality includes eating with the guest, playing traditional village games for the guest's enjoyment, and enjoying their cultural music, the rabab. However, with time, along with other cultural changes, it changed and the traditional hujras are on the way to be replaced by Beithak, which is equally popular in both the village and the city. This is where the family offers hospitality to the guests. 


\section{Respect for Women}

In Pakhtun families, women have a special place of honor and respect. No economic burden is placed on women. She lives a life of her own free from any kind of mental anguish. Her job is to take care of the children, husband, and other family members. Thus, she has the status of the queen of the house. In the traditions, values, and culture of Pakhtunkhwa, respect for women is obligatory on every individual. Because of this honor and dignity, they are also called Tor Sree in Pashto. Pakhtun men consider it their cowardice to raise their hands against them. They consider it against their honor and masculinity to oppress them. The Pakhtun tribes pay special attention to the dignity of women even if there is war. In times of war, when women provide water and food on the front lines, the opposing tribe stops firing so that the woman does not get hurt. Harming a woman is considered impotence in Pashtun society (Khattak 2008). Pashtuns especially focus on Islamic education and training of girls so that they may use them to guide their own lives and those of future generations.

\section{Dress Code}

Allah says in the (Quran 7:26),

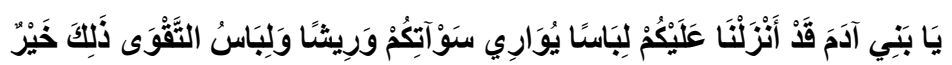

O children of Adam, we have bestowed upon you clothing to conceal your private parts and as adornment. But the clothing of righteousness - that is best.

Clothing is very important in the culture of Khyber Pakhtunkhwa. Khyber Pakhtunkhwa's dress is slightly different from the rest of the world's cultural dress. Pashtun men's clothing consists of Shalwar and Kameez. However, the circumference of the Shalwar varies from area to area. Pashtun women take special care in choosing their clothes so that it meets the need of modesty. Shalwars and shirts are very long. The dress of the people of Khyber Pakhtunkhwa (men and women) is following Islamic requirements, and it focuses on the element of modesty and veil, which leaves a positive effect on the personality of an individual (Durrani 1982).

\section{Wedding Rituals}

Marriage rituals reflect the cultural values and traditions of the Pakhtuns. Keeping in view the veil of women, separate places are arranged for men and women during the marriage ceremony. Dowry is not demanded by the bridegroom. Rather, the groom is responsible for all the expenses. The occasion of marriage is very important for every girl. On this occasion, the girl is given special gifts by the boy, which includes good clothes and gold jewelry. The ceremony is held indoors. Arrangements are made for women inside the house and men outside the house. All these arrangements are made by all the members of the family together.

In Pashtun society, the engagement ceremony is performed before marriage. In some families, the marriage ceremony is also performed on this occasion because it is considered improper for the groom to come to the bride's house after the engagement in Pakhtuns. On the Wedding day, attendees start arriving in the morning to the house of the bridegroom. They leave for the bride's house in the afternoon to have a meal in the form of a Barat. During the occasion, women play drums, sing their traditional songs, and praise the bride and groom in the songs. On this occasion, various gifts are given to the girl by the relatives (Durrani 1982).

\section{Western Culture}

\section{Freedom}

Western culture is based on freedom. It does not impose any kind of restriction. The principle of freedom is that man has intellect, and he can realize his good and bad deeds. He does not need any guidance from God, religion, culture or civilization, relationships etc. He can understand his advantages and disadvantages. According to Western culture, man is born free. That is, it is free from all kinds of religious, cultural, cultural and traditional values and principles and family pressures (Ahmad 2014).

\section{Development}

The goal of life in the West is material progress in technology, economics, and politics. In this race for progress, it has given open freedom to men and women to achieve development. The entire management of the house has been handed over to the market for development. No one has time to manage the household affairs. Women have been pushed out of their homes to achieve development. Women have been given equal obligations to men in all matters of livelihood. Women have gone so far in this race for development to consider the training and upbringing of her children a burden. She no more needs a husband and regards modesty as a prison for herself. The race for women's livelihood 
has led to state development, but the family system has fallen into disarray. This has destroyed the roots of the family system.

\section{Equality}

The West raises voice for the women's rights and claims to be the forerunner in giving rights to women equal to men. However, it has also made women vulnerable, and they are mainly used for sexual gratification. Women are bought and sold to fulfill their sexual desires. There is no difficulty in buying and selling. Sarwat Jamal writes quoting the August 3 report of the Sami Guardian that in Western society, men generally prefer to buy and sell women to satisfy their sexual desires. The plight of women in Western culture can be judged from the report, which estimates that about 4,000 women are imported each year to meet the demands of the sex industry, according to a Western survey (Jamal 2012). Moreover, the safest place for a woman is her home, where she feels safe from all kinds of dangers as she is with her husband, children, relatives, and neighbors. However, home has become a dangerous place for a woman in the West, where she is more likely to be killed by her current or old acquaintance about the house.

\section{Promoting Western culture in Khyber Pakhtunkhwa}

Secularism is one of the major principles of western culture. Secularism is an English word, which means the belief that the organization and management of a society or a community should not be founded on religion or religious dogmas and principles (Hornby and Cowie 1995). According to the philosophy of secularism, man is free from religion. It holds that man's life depends upon morality, and all matters in life, which are based on ethics and education, should be free from religion. A secular man neither has any concern with religion nor with God. There came a time in Western society when anti-religious sentiments were rampant in the hearts of the people, so thinkers thought that knowledge is anything that is not religion. Knowledge has nothing to do with religion. Some Arab literary men and scholars were so affected by the idea that they termed it as 'ilmaniyyah' i.e. about knowledge (Farhad n.d). Secularism has played a major role in bringing the Western family system to the brink of collapse. Before secularism, the Western family system was also based on religious values and traditions. But secularist thinkers popularized secularism and left religion behind to promote liberalism and new ideas.

\section{Liberalism}

Liberalism is the name given to the idea that every individual has total independence in his life. He lives life according to his desires without interference from other members of the community, religion, or state. In other words, liberalism is the name of complete freedom of the individual. The slogan of liberalism rose against the oppression and monopoly of the church system and the feudal system in Europe. It gave birth to the enlightenment movement, which became a movement against all forms of sanctions. This movement took the form of mental anarchy in individuals. The meaning of this enlightenment is that the individual is free religiously and socially (Qamar 2018, July). Nowadays, liberalism is also flourishing in Khyber Pakhtunkhwa. Liberalism is responsible for the mental, cultural and moral changes in the family system. Due to liberalism, there are signs of aversion to religion in the family system. Young people are becoming disillusioned with the beliefs and faith of the older generation. The distinction between good and bad deeds is on the way to disappear.

\section{Sources of Promotion of Western Culture NGOs}

History shows that the tyrannical powers in every age are constantly fighting against the truth with new tactics. Currently, various NGOs are designed to achieve this goal. External forces, including the United Nations, multinational corporations, and the World Bank, are working to achieve the goals of these powers. These tyrannical powers provide funds in billions to these NGOs to achieve their goals. They seem to be working for human rights, women's emancipation, and women's development and prosperity (Qazi 2009). All the NGOs seem to have a slogan for the welfare of the people. People also think that they want their development. But, behind the scenes, they are active in line with the Western agenda. Their employees do what the Western world wants them to do. NGOs target the naive and illiterate members of society because their thinking changes easily. Some of them are actively engaged in propagating the teaching of the Torah and the Gospel and argue that these are heavenly books that change with time and circumstances to suggest solutions to the present-day problems. One must go against Islam to some extent to achieve one's goal and popularize Westernization and modernity. 


\section{TV Dramas}

In the present era, TV drama is playing a vital role in the promotion of Western culture. TV has wreaked havoc with the traditional values. TV has caused utter damage to religion and religious values and norms. TV presents commercials of new fashions which attracts the rich and the poor. They are presented so attractively that people often go beyond their monthly budget to adopt the latest fashion. To fulfil the desires of their family, men forget the distinction between halal and haraam. Moreover, TV is playing a vital role in spreading immodest dress culture through commercials and drama, which in turn spread nudity in the society. Young girls and boys are being taught the values and norms of the Western culture through TV dramas. Through attractive scenes, highlighting Western norms of liberalism, obscenity, illegal affairs between girls and boys, theft and dacoity are inculcated to the young girls and boys (Al-Qadri 2012).

TV dramas play a crucial role in promoting Westernization. The actors shown on TV are shown wearing western clothes, which are the focus of people's attention. To promote obscenity and nudity, a woman is shown that she is very strong, so she does not need a veil or a headscarf. Training children is a difficult task. The cartoons shown on TV ruined the training of children. The family system is being destroyed by showing on TV dramas the source of progress and success in the West (Saeed 2018 December 11).

\section{Internet}

The use of the Internet is so prevalent today that it would not be wrong to say that the young generation cannot survive without the Internet in the same way that human beings cannot survive without food. Young boys and girls chat all day and night and are fooled by each other with lies. This is a waste of time chatting all the time on the internet and visiting rude Western sites. In the race for Western development, young people waste all their energy, money, and time on the Internet. With relentless use of the Internet, the wife has no time for her husband and the husband has no time for his wife. Neither the parents have time for the children nor have the children time for their parents. It has caused social distancing from the family members to have online interaction with non-family members. Consequently, the Pashtun family system is on the way to disruption, and the traditional values for honor and respect diminish with every passing day.

\section{Mobile Phone}

Like the Internet, the mobile phone is at the forefront of the destruction of a new generation and the promotion of Western culture. Young people, while adopting Western styles of using phones, are stuck in the mire of mobile phones. In the Western traditional way, non-mahram girls and boys in Pashtun culture talk obscenely on mobile phones, which is spreading obscenity. Moreover, we are losing our critical aptitude, and we do not confirm the correctness of information before spreading it further. It has caused the spread of misinformation among our current generation.

\section{Review of Cultural Changes in Khyber Pakhtunkhwa Nuclear Family System}

Pashtun society was remembered in the world because of its joint family system. Today, Western thinking has forced people to adopt the nuclear family system. The practice of nuclear family systems is growing rapidly. The demand for a separate house starts immediately after marriage. People living in nuclear families are not dependent on other relatives. They do not have the sincerity, love, unity, and harmony that are found in members of a joint family. The nuclear family system is disrupting the stability of the Pashtun family system, as it has led to social distancing between the close relatives of the family due to preoccupation with one's own nuclear family. Due to these growing distances, a gap is emerging between the old and new generations. Traditional values of respect for elders and grooming of the younger in the traditional manner are waning. They do not respect him and do not consider his service as a way of salvation for themselves. Since Islam does not encourage a joint family system, it focuses on building relationships within the clan and family. In the Pakhtun family system, the Western nuclear family system is gaining momentum. The lack of distinction between elders and Youngers is decreasing, and respect for teachers and elders is diminishing day by day. Relatives' rights are being ignored. Relationships are growing tense and distant. The family system seems to be deteriorating (Shahid 2018).

\section{Co-education System}

The education system of a nation is of great importance in strengthening its family system. In modern times, Pashtuns focus on the western education system, and parents try to inculcate their children 
education in western style. The aim of quality education is the civilization of the new generation and the training of living a decent and upright life. However, the introduction of coeducation in our society on western style has done more harm than good. Students are more interested in adopting new fashions, as they learn from different commercials than their studies. Smartphones, hairstyles, tight trousers, half sleeves, unveiled chest, and lack of scarf are more preferred by girls than their studies. These trends lead to the attraction of male towards female, which then lead to moral depravity and unethical character building. It leaves negative effects on the culture and family system in Pashtun society, where the norms are veil and modesty (Benori n.d). Jihad, Sira Sahaba, and Islamic values and traditions are removed from the curriculum. Parents are more interested in the teaching style of convent schools and Oxford and Cambridge universities (Munib 2008).

An Orientalist Hamilton Gibb states that the real purpose of imposing Western culture on Muslims is to destroy Islamic culture because this civilization is the basis of the unity of Muslims. Changes in Islamic culture should be brought about through their educational, cultural, and media means, which will alienate Muslims from their religion and they will not even realize it (Babar 2018).

Girls in educational institutions are growing up prematurely and are suffering from all kinds of superstitions. At an early age, friendship and affection are built between boy and girl. There is such an atmosphere of misguidance in colleges and universities that young boys and girls become so close and intimate with each other that they cover all the distances and go astray without knowing it. Moral depravity, nudity, and pornography in schools, colleges, and universities are the fruits of this coeducation system.

\section{Wedding Rituals and the West}

Like the rest of Khyber Pakhtunkhwa's rituals, marriage has changed. People seem to be fascinated by the West even in marriage and marriage ceremonies. In Western style, the boy and the girl express their love for each other, and then they decide to become united in wedlock. Thus, the decisions that adults used to make are now made by the boy and the girl themselves.

In the engagement ceremony, the boy and the girl make get each other wear rings, which is not permissible according to Shari'a. In Shari'a, both the boy and the girl are non-mahrams for each other before marriage. Besides, non-mahram men and women who participate in this ceremony show low mannerisms towards each other. There is no arrangement of curtains. They laugh and cut jokes at each other without any hesitation (Munib 2008). This is followed by the rite of betrothal. In modern times, marriage is considered incomplete without a movie maker. Usually, a bride adores herself only for her husband, but in the present era, the camera starts moving even before the bride is ready. The man with the camera not only looks at the bride, but also asks her to make poses as he pleases. The father and the husband, who used to deny anyone even to look at his daughter/wife, now give open permission to the movie maker to see her from whatever angle he can see her and pay him a sufficient amount. Even before the marriage, the bride and groom go to the studio and make big pictures that fall under the category of influential western imitation (Munib 2008).

\section{Family Planning}

Residents of Khyber Pakhtunkhwa who considered having more children as the sign of their dignity and power, and felt proud of them, are now following the western tradition of having a small family. For this purpose, they have adopted various family planning methods to stop the reproduction of children. These ways are also the result of blind following of the West. Various contraceptives are used by the people for birth control. Contraceptive measures have been emphasized and disseminated among the public so that the information reaches every adult male and female.

The famous English economist Malthus started this movement of birth control. At that time, the population of England was growing rapidly. According to Malthus, the habitat of the earth is limited, the economy is limited, and the breeding is unlimited. And if humans continue to grow at its natural rate, the earth will no longer be habitable and will be too short to live. Therefore, to improve the quality of life, breeding should be stopped. For which Malthus insisted on adopting the method of Barham Church. That is, marriage should be performed at an older age and self-control should be exercised after marriage (Maududi 1961). Influenced by Western values, Pashtuns are adopting methods family planning and family control measures to keep their families small and avoid problems associated with larger families. It will help their children to get good education and have a good and standard social life. 


\section{A Reflection of the West in Clothing}

Clothing serves as adornment and covering for the body parts of a person. There is also a marked change in the dress of the people of Khyber Pakhtunkhwa. Young girls now often prefer pants, shirts, and jeans. Scarf, a symbol of Pashtun girls, is now considered as the symbol of backwardness. Similarly, boys also prefer western dressing instead of traditional Shalwar and Kameez. Fashion in the dress is on the surge. Sometimes the shirt is tight, and the straps are so small that a woman's hips can be seen while moving. Sometimes the chalk is so long that a woman's abdomen and hips are visible. The length of the shirt is sometimes above the knees, sometimes up to the thighs and sometimes up to the navel, which does not meet the requirements of the woman's veil. The neck of the shirt is kept so wide that if the woman bends down a little, the part of the body which is called the covering is also visible. The cloth is so thin that a woman's whole body is visible (Munib 2007). Today, in the imitation of Western culture, their dress styles have been adopted by the youth. Educational institutions, which are the center of teaching and learning, are no place for competition for expensive clothes. Young girls' clothes no longer cover their whole body. Sometimes, so much thin clothes are worn that the body can be seen. The same is true of young boys, who have put aside their own culture in imitation of the west and wear clothes that make their physical features more prominent. Worn out jeans are now put on by boys and girls alike.

\section{Discussion and Conclusion}

In modern-day globalization, not only western trade goods are being exported to Eastern countries, but the western ideas, civilization, and way of life are knocking on the doors of our eastern society. Western influences on our culture are quite evident. Cultural change is a phenomenon that occurs when the cultural values of one society are adopted by another. Residents of Khyber Pakhtunkhwa are also turning away from Islamic teachings and are turning to the West. Western culture and ideas are being imitated in speech, dress, food and drink, marriage rituals, situations of grief, etc.

Islam has attached great importance to the family system. Family is the first school of education for children, where the architects of tomorrow are brought up. If this school becomes a victim of chaos and anarchy, then there will be chaos in the whole society. That is why Islam has articulated its detailed rules about the family system.

The Western family system is in disarray. The roots of their family system are undermined. This is largely due to the principles of their family system, which are based on the man-made ideas and philosophies of their thinkers. They have established their values and traditions, which depend on freedom from religion and culture. As this freedom is unrestrained, therefore, the West is in turmoil. Pornography and nudity are on the rise. Homosexuality is common. Parents are being abused. Parents cannot say anything to their children about their mistakes. The honor of parents is being violated. Daycare centers are responsible for training children.

The credit for this change goes to the media and the Internet. Our media reflects Western thinking. As a result, the evils of the West are permeating our family system. West is imitated and followed blindly without looking for the preservation of our cultural values and norms. This attitude is on the way to destabilize the Pashtun family system and the Pashtun society.

\section{References}

Ahmad, M. (2014). Ta'aruf e Tehzeeb e Maghrib Aur Falsafa e Jadeed. Karachi: Karachi University Research Forum.

Al-Qadri, M. T. (2012). Jadeed Masayel ka Islami hal. Faisalabad: Nayab Printers.

Avruch, K. (1998). Culture \& conflict resolution. US Institute of Peace Press.

Babar, A. (2018). Pakistani Saqafat par Maghrabi Saqafat ki Fekri Yalghar. Dukhturan e Islam. Lahore: Minhaj-ul-Quran.

Benori, M. Y. (n.d). Islam main Taaleem-e-Niswan aor Mojuda Makhlut Nizam-e-Taaleem. Karachi: University of Islamia.

Bukhari, I. (1981). Sahih al-Bukhari. Cairo: Dar El Shaab.

Durrani, A. Q. (1982). Pashtun Culture. Quetta: Pashto Academy Baluchistan, Quetta.

Farhad, S. (n.d). Secularism. Lahore: Ketab Mahal.

Hafeez, A. (1999). Misbah ul Lughat. Lahore: Maktabah Quddusiah.

Hornby, A. S., and A. P. Cowie (1995). Oxford Advanced Learner's Dictionary. Oxford University Press Oxford.

Jamal, S. (2012). Aurat, Mghreb aor Islam. Islamabad. Institute of Policy Studies. 
Khattak, R. W. S. (2008). Pashtunwali, Pashtoono ka tarzay Hayat aur zabita-i-Akhlaq. Peshawar: Pashto Academy, University of Peshawar, and Lok Virsa Islamabad.

Manzur, I. (1988). Lisan al-'arab. Bairut: Dar Ihya Turath Arabiy.

Maududi, A. A. a. (1961). Islam aor Zabt-e-Wiladat. Lahore: Islamic Publishers.

Munib, M. A. (2007). Aurat ka Lebas. Lahore: Elam o Hekmat.

Munib, M. A. (2008). Shadi ki Rasumat, Dawatin aor UN main Shirkat. Lahore: Dar al-Kuthub, AlSalfia.

Munib, U. A. (2008). Makhlut Taaleem. Lahore: Mushraba Elam-o-Hekmat.

Muslim, I. H. (2014). Sahih Muslim. Lahore: Nughmani Kutubkhana.

Qamar, A. J. (2018, July). Liberalism aur is ke Asaraat. Minhaj Al-Quran. Lahore, Minhaj-ul-Quran Movement.

Qazi, S. R. (2009). Islam ka Khandani Nizaam or 'Asri thahzibi thahdiyat. Department of Islamic Studies. Lahore: University of Lahore. Ph. D.

Saeed, M. (2018 December 11). Marghrebi Tehzib ke Asaraat. Nawaiwaqat. Islamabad, Nawaiwaqat Group.

Shahid, S. M. (2018). Pakistani Ma'ashra aur Saqafat. Lahore: Evernew Book Palace.

Spencer-Oatey, H. (2008). Culturally Speaking: Culture, Communication and Politeness Theory. Bloomsbury Publishing.

Toru, M. I. (n.d.). Al-Huda International. Rawalpindi, Darul Afta Jamea Islamia.

Williams, R. (2018). Popular culture: history and theory. Cultural Studies 32(6): 903-928. 